\title{
Community plantation forests in Indonesia Challenges and policy recommendations
}

\author{
Hariadi Kartodihardjo ', Bramasto Nugroho ', Dede Rohadi ${ }^{2}$, Didik Suharjito ${ }^{1}$ and Ahmad Dermawan ${ }^{3}$
}

\section{Key messages}

- The Ministry of Forestry's community plantation forests programme, established in 2007, aims to provide communities with access to forest resources.

- Despite government support in policies and funding the programme has fallen far short of its targets.

- Researchers interviewed stakeholders at national and local levels to identify obstacles to success and steps to ease the way forward. We have four main recommendations for the Ministry of Forestry and several others detailed in the conclusions.

- To increase the success of the CPF programme, the Ministry of Forestry could:

» simplify land designation and permitting processes, reducing transaction costs for smallholder farmers;

» facilitate access to loans and make loan size more flexible to serve smallholders familiar with IDR 1-2 million loan schemes;

» expedite community timber transportation and better access to markets through coordination with provincial and district forestry offices;

» coordinate with district forestry offices to establish forestry extension activities to improve stand quality and yield.

\section{Introduction}

The community plantation forests (CPF) programme was established in 2007 by the Ministry of Forestry with the aim of increasing community involvement in forest utilisation. The Ministry of Forestry has the authority to issue permits. It has delegated this authority to district heads to simplify the permitting process. The CPF programme receives substantial financial support from the government, through the Forest Development Funding Centre (FDFC), which is

\footnotetext{
1 Faculty of Forestry, Bogor Agricultural University

2 Forestry Research and Development Agency (FORDA)

3 CIFOR
}

a public service agency under the Ministry of Forestry. The government has budgeted about IDR 43.2 trillion to fund CPF development from 2007 to 2016 (Ditjen BPK 2007).

CPF permit holders can submit loan applications to the FDFC and secure loans for standard CPF costs, with interest charged at the rate set by the Deposit Insurance Institution. Standard CPF costs to develop timber plantations are IDR 9.1-12.6 million per hectare (ha) to cover planning, infrastructure development, payment of land tax, planting, maintenance, and protection of timber plantations. However, since the Ministry of Forestry carries out planning and infrastructure development, CPF permit holders will receive loans of IDR 8.6-11.9 million per ha. CPF permit 
holders have an 8-year grace period to repay the loans. The funding scheme also requires that farmer groups applying for a loan have at least five members. These groups must be authorised by a village head, with the knowledge of the head of the district or municipal forestry office. They must also secure assistance from facilitators appointed by the district head or mayor.

The government recognises three types of CPF development:

- $\quad$ independent CPF permit holders, who develop plantation forests using their own funds;

- partnership CPFs, which involve third parties in developing plantation forests; and

- developer CPFs, where a company or state-owned enterprise develops a CPF, which it will subsequently surrender to a CPF permit holder in exchange for the cost of CPF establishment.

The CPF programme was expected to become a vehicle for communities to secure benefits from forest resources. The government set targets and benchmarks for designating forests and for actual planting. By 2010 the Ministry of Forestry had aimed to designate 5.4 million ha for CPF schemes and have 1.97 million ha of that area already planted. By 2016 the Ministry of Forestry expected to have 5.4 million ha of forest planted under the CPF programme, creating jobs for 360000 households.

Although the government has provided various facilities to support CPF development, the programme's achievements are well below official targets. By the second quarter of 2011, the Ministry of Forestry had approved CPFs on just 650663 ha in 26 provinces. Of this, district heads had issued 1857 CPF permits for only 127244 ha in 17 provinces (Ditjen BUK 2011). Figures for the land area already planted are unavailable; since most permits were granted in 2010, the area already planted is likely to be small. This brief describes the factors obstructing CPF policy, examines ways to encourage CPF development, and makes recommendations for improvement.

\section{Permit application and provision processes}

To ascertain why the CPF programme has not achieved its targets, researchers conducted interviews with policy makers, villagers and other stakeholders in Jakarta, Riau and
South Kalimantan. The data indicate a number of obstacles that prevent CPF development targets from being attained.

Although the CPF permitting processes were designed to be simpler than those for large-scale industrial timber plantations, they are still too complicated for community stakeholders. Forestry officials in Riau and South Kalimantan said that the rules governing permitting, planning, and development of CPFs and trading of timber are overly complex. Communities need help from forestry extension officers to obtain permits, but none is available. Communities also question the fact that permits cannot be passed down or inherited. For example, if the head of household who is the permit holder dies, the CPF permit must be returned to the government irrespective of how well the plantation forest is being managed (Obidzinski and Dermawan 2010). This greatly reduces business certainty. Since this requirement is defined by the Forestry Law, removing this constraint would mean revising the law.

The Ministry of Forestry must identify forest areas that are not under licence for other purposes to designate as CPF sites. Such sites are extremely hard to find. This approach also pays little attention to the location of communities and their socio-economic conditions. Areas designated for CPFs are often too far from communities, or communities are not interested in developing CPFs in those locations.

In addition, relationships among government institutions are weak, and different interpretations of CPF policies prevail. For example, whether all of the area under CPF permit should be planted solely with timber or whether communities can plant agricultural crops to support their livelihoods before the trees are harvested is a matter of dispute.

\section{Funding schemes}

The FDFC plays a dominant role in channelling and managing the revolving loans for the CPF programme. The FDFC's function is to evaluate loan applications and approve or reject them. However, the FDFC does not have regional offices, which would make them more accessible to their target groups. Applicants from anywhere in Indonesia must apply to the FDFC office in Jakarta. The FDFC must also visit every location to evaluate applications, which is difficult given its relatively low operational budget.

By September 2011, the FDFC had received 141 applications for loans, from 135 forest farmer groups and 6 cooperatives, 
and distributed IDR 29 billion in loans (Kementerian Koordinator Bidang Perekonomian 2011). However, this achievement fell far short of the government's target of IDR 482 billion by the end of 2011 (Natalia 2011).

Another obstacle related to funding is that the 'one size fits all' scheme limits communities' borrowing options. According to surveys in Riau and South Kalimantan, respondents generally own less than IDR 20 million in movable assets. Most respondents have never borrowed more than IDR 1 million per year. Most borrow to meet subsistence needs and to provide capital for farming. This makes it difficult for community members to manage the standard CPF loan of IDR 9-12 million per ha (Nugroho 2010).

\section{Farmers' reluctance to engage in timber crop enterprises}

Farmers in Riau and South Kalimantan provinces have had negative experiences with community timber enterprises and planting trees as a commercial commodity. In Riau, the government conducted a programme to encourage farmers to plant sengon (Paraserianthes falcataria), but the government did not help ensure market absorption for the timber. In South Kalimantan, a company persuaded farmers to plant kadam (Anthocephalus cadamba) with a promise to absorb the timber. However, by the time the timber was ready for harvest, the company had closed. This has indirectly reduced regional governments' political will to implement the CPF programme.

Research in Tanah Laut District, South Kalimantan shows that community timber plantation businesses are economically viable, but may not be the best option to provide family income. Tree crops take a long time to grow before the harvest can generate income for farmers. Rubber and oil palm provide better returns for communities. On the other hand, timber crops require less capital investment than other farming activities, both in terms of procurement costs (developing crops) and maintenance. For farmers with relatively large areas of land, tree crops can be an attractive savings option since farmers generally have limited manpower (Rohadi et al. 2010).

When farmers sell their timber, they frequently have to accept the prices set by timber traders. They have limited market information and little choice among buyers. In marketing community timber, farmers and wood traders are still burdened by the obligation to secure log transportation documents or certificates of timber origin. Even though such documents can basically be obtained free of charge from district forestry offices (for log transportation documents) or village heads (for certificates of timber origin), this obligation leads to significant transaction costs. Farmers have to travel to the district centre to arrange the documents, and they often have to make informal payments, such as at police checkpoints, when the timber is transported. These provide disincentives for farmers to plant tree crops.

\section{The role of extension officers}

In terms of the potential of existing tree stands, the quality of communities' tree crops is quite variable. This indicates that the effectiveness of farmers' silviculture techniques still varies (Kallio et al. 2010). Consequently, farmers need capacity building in crop cultivation management. Interviews showed that farmers generally learn from people other than extension officers, such as farmer groups or companies. This shows the importance of increasing the role of extension officers in facilitating technology transfer in timber crop cultivation techniques. Extension officers can also help farmers choose silvicultural techniques that are suitable to local conditions.

Extension officers can act as information sources and service providers for farmers to utilise government programme opportunities to develop community timber crops, such as the CPF programme. Observations and interviews with farmer respondents in Tanah Laut District indicate that most communities have yet to receive sufficient information on the CPF programme.

\section{Conclusions and policy recommendations}

The CPF programme is an important means to improve community access to the benefits of timber plantation enterprises. The government's efforts to provide communities with access to social forestry are restrained by shortcomings in the allocation and permitting processes. Land designated for CPFs is frequently located far from farmers' homes.

The provision of substantial funding, and interest rates lower than commercial bank rates have yet to entice farmers to borrow from the FDFC. The location of the FDFC office in Jakarta, with no provincial or district offices, makes it difficult for farmers to arrange loan applications, and for FDFC officers to assess the applications. Further, the inflexibility of the borrowing scheme makes farmers reluctant to borrow.

Farmers' experiences have also affected their acceptance of the CPF programme. Past failures to market wood have influenced their view of the programme. This is reinforced by 
the poor earnings from timber crops in comparison with alternative crops. Rubber and oil palm generate bigger net earnings than community timber estates.

Farmers' silvicultural practices have much scope for improvement. However, the lack of forestry extension officers remains a major challenge. Consequently, farmers generally learn about cultivation techniques from other farmers or from their own experiences.

Considering these challenges, the Ministry of Forestry has a number of policy options for making the CPF programme more successful.

Secure permitting of eligible forests areas. The Ministry of Forestry needs a clear picture of the extent and location of forests which are free of existing rights. In permitting, business certainty will encourage participations, so permits could be protect from remittance in the event of a permit holder's death. Establishing more secure usage rights will help communities manage their plantations. This is particularly important since the CPF permit could be valid for up to 100 years.

FDFC loans. Easier access to FDFC loans will speed planting. The FDFC could establish offices at least at the provincial level, offices that could respond more rapidly to requests for information and loans. The FDFC could consider partnering with the banking sector or a number of rural financing programmes to facilitate the lending process. In addition, the FDFC could also consider making loan schemes more flexible, adjusted to the capacity of farmers to handle them.

Marketing. In light of community perception indicators and doubts expressed by farmers, community timber businesses might be made more attractive if farmers' profits could be increased. To motivate communities to plant tree crops, the government could create market opportunities and lower transaction costs in marketing the produce of community tree crops.
Extension services. The government needs to increase its extension services to farmers with tree crop enterprises. Such extension programmes should not be limited to technical aspects of cultivating tree crops but should also cover more general aspects, such as permitting processes and timber business management systems.

\section{References}

Ditjen BPK (Directorate General of Forestry Production Management) 2007 Pembangunan hutan tanaman rakyat (HTR). Directorate General BPK, Jakarta, Indonesia.

Ditjen BUK (Directorate General of Forestry Enterprise Management) 2011 Data release, Ditjen BUK Triwulan II Tahun 2011. Directorate General BUK, Jakarta, Indonesia.

Kementerian Koordinator Bidang Perekonomian 2011 Liputan hasil wawancara dengan BLU Pusat Pembiayaan Pembangunan Hutan: pembiayaan sektor kehutanan melalui dana bergulir Kementerian Kehutanan. Tinjauan Ekonomi dan Keuangan 1(9): 14-15.

Kallio, M., Krisnawati, H., Rohadi, D. and Kanninen, M. 2010 Mahogany and kadam planting farmers in South Kalimantan: The link between silvicultural activity and stand quality. Small-scale Forestry 10(1): 115-132.

Natalia, G. 2011 Kemenhut pesimis salurkan sisa 91\% BLU. Bisnis Indonesia, 3 October. http://www.bisnis.com/ articles/kemenhut-pesimis-salurkan-sisa-91-percent-blu (8 October 2011).

Nugroho, B. 2010 Pembangunan kelembagaan pinjaman dana bergulir hutan rakyat. Jurnal Manajemen Hutan Tropika 16(3): 118-125.

Obidzinski, K. and Dermawan, A. 2010 Smallholder timber plantation development in Indonesia: What is preventing progress? International Forestry Review 12(4): 339-348.

Rohadi, D., Kallio, M., Krisnawati, H. and Manalu, P. 2010 Economic incentives and household perceptions on smallholder timber plantations: Lessons from case studies in Indonesia. Paper presented at Taking stock of smallholder and community forestry: Where do we go from here?' Montpellier, France, 24-26 March.

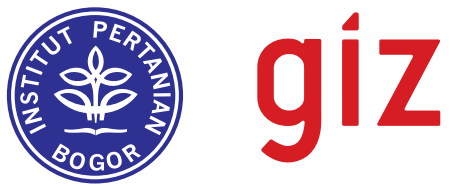

